\title{
Férfi hormonális fogamzásgátlás: múlt, jelen, jövő
}

\author{
Pásztor Norbert dr. ${ }^{1}$ - Hegyi Borbála Eszter dr. ${ }^{2}$ \\ Badó Attila dr. ${ }^{1}$ - Németh Gábor dr. ${ }^{1}$ \\ Szegedi Tudományegyetem, Általános Orvostudományi Kar, ${ }^{1}$ Szent-Györgyi Albert Klinikai Központ, \\ Szülészeti és Nőgyógyászati Klinika, ${ }^{2}$ Klinikai Orvostudományok Doktori Iskola, Szeged
}

\begin{abstract}
A világ egyes részein a népesség nagyarányú növekedése komoly gazdasági és népegészségügyi kihívást jelent, míg más országokban a hatékony fogamzásgátlási igényt személyes motivációk határozzák meg. A jelenleg széles körben hozzáférhető fogamzásgátlási módszerek java része a nők feladata, míg igen korlátozott azoknak a módszereknek a száma, amelyekért a férfi a felelős. Korábbi tanulmányok alapján ismert, hogy a terhességek jelentős hányada nem kívánt terhesség, illetve, hogy lehetőség esetén a férfiak a fogamzásgátlásban nagyobb szerepet vállalnának. Többek között emiatt indultak el az elmúlt évtizedekben olyan vizsgálatok, amelyek egy megfeleló férfi hormonális fogamzásgátlási módszer kifejlesztését tűzték ki célul. A módszer alapja a külsőleg bevitt hatóanyaggal az agyalapi mirigy folliculusstimuláló és luteinizáló hormon elválasztásának gátlása, amely következményesen gátolja a here tesztoszteronés spermiumtermelését is. A témában megjelent tanulmányok először tesztoszteronszármazékot, majd annak elégtelensége miatt tesztoszteron-gesztagén kombinációt alkalmaztak, később megjelentek a szintetikus androgén vegyületek is. Az elért eredmények egyelőre nem teszik lehetővé az ilyen jellegű fogamzásgátló módszerek biztonságos, széles körű alkalmazását, de a jövőben elképzelhető, hogy az akadályok leküzdését követően, a fogamzásgátlás területén a férfiak is több lehetőséget kapnak.
\end{abstract}

Orv Hetil. 2017; 158(46): 1819-1830.

Kulcsszavak: férfi, hormonális, fogamzásgátlás

\section{Male hormonal contraception: past, present, future}

In certain regions of the world the enormous rate of population growth raises economic and public health concerns and widely accessible contraceptive methods would be desired. In contrast, in other countries the use of effective contraception is a question of individual preferences. Today, most of the reliable contraceptive methods are applied by women, while the options for male methods are quite limited. It is well known that significant portion of pregnancies are still unplanned and several data revealed men's willingness to take part in family planning. Based on these needs, remarkable efforts have been made to develop a suitable hormonal contraceptive agent for men. With the exogenous suppression of follicle stimulating hormone and luteinizing hormone secretion, the inhibition of the testicular testosterone production and the spermatogenesis can be achieved. In the beginning, testosterone-derivatives, or testosterone-progestin combinations were administered, later synthetic androgen agents were developed. Despite of these efforts, unfortunately, there is no safe, widely feasible male hormonal contraception to date, but in the future this goal can be achieved by solving the key hurdles.

Keywords: men, hormonal, contraception

Pásztor N, Hegyi BE, Badó A, Németh G. [Male hormonal contraception: past, present, future]. Orv Hetil. 2017; 158(46): 1819-1830.

(Beérkezett: 2017. augusztus 4.; elfogadva: 2017. szeptember 11.)

\section{Rövidítések}

BRD4 = (bromodomain-containing protein 4) bromodomént tartalmazó protein 4 ; BRDT $=$ (bromodomain testis-specific protein) bromodomén herespecifikus fehérje; DHT = 5-alfa- dihidrotesztoszteron; DMAU = dimethandrolon-undekanoát; DMPA = depo medroxiprogeszteron-acetát; FSH = folliculusstimuláló hormon; GnRH = (gonadotropin-releasing hormone $)$ gonadotropinfelszabadító hormon; EPPIN = (epididymal pro- 
tease inhibitor) mellékhereproteáz-inhibitor; ET = etonogestrel; HDL = (high-density lipoprotein ) magas súrúségú lipoprotein; $\mathrm{LDL}=$ (low-density lipoprotein) alacsony sűrúségú lipoprotein; LH = luteinizáló hormon; LNG = levonorgestrel; $\mathrm{KSH}=($ Hungarian Central Statistical Office $)$ Központi Statisztikai Hivatal; MENT = 7- $\alpha$-metil-19-nortesztoszteron; NES = nestoron; NETE $=$ norethisteron-enantát TE $=$ tesztoszteron; TE-EN = tesztoszteron-enantát; TE-UN = tesztoszteron-undekanoát; $\mathrm{WHO}=($ World Health Organization $)$ Egészségügyi Világszervezet

Az elmúlt évtizedekben az urbanizációnak, a szociális és a gazdasági fejlődésnek köszönhetően a párok egy része a korábbi tradíciókhoz képest kevesebb gyermeket szeretne vállalni [1]. Ezen életmódbeli változás miatt a megbízható fogamzásgátlás szerepe világszerte felértékelődött. Igazolt, hogy a nem kívánt terhességek negatív fizikális és mentális egészségi, illetve anyagi következményekkel járnak, amelyek nemcsak a várandós nőt, hanem annak megszületendő gyermekét is érintik [2]. Annak ellenére, hogy a reproduktív korú nők körében a fogamzásgátló tabletta használata a fejlett országokban és egyes fejlődő országokban a $62-73 \%$-ot is eléri $[2,3]$, a világon a terhességek mintegy $40 \%$-a továbbra is nem kívánt terhesség [1]. Becslések szerint a nem kívánt terhességek 50\%-a terhességmegszakítással, 12\%-a vetéléssel, míg 38\%-a szüléssel végződött 2012-ben [1]. A nem kívánt terhességek sorsát nagymértékben befolyásolják a kulturális és szociális tényezők, illetve a legális terhességmegszakítás hozzáférhetősége. Magyarországon 2015-ben az élveszületések száma 91 690-nek, míg a terhességmegszakítások száma 31 176-nak adódott (KSH Statisztikai tükör, Népmozgalom). Bár magyar adattal nem rendelkezünk arra vonatkozóan, hogy hazánkban a szülések hány százaléka származik nem kívánt terhességből, de az előzóleg ismertetett adatok alapján a nem kívánt terhességek előfordulása nagyságrendileg legalább 30$35 \%$-ra becsülhető.

Hatékony fogamzásgátlás alkalmazásával a nem kívánt terhességek nagy része természetesen megelőzhető. Egy korábbi, hazai vizsgálat alapján a 20 év alatti, szexuálisan aktív nők 40,8\%-a, míg a 20 év feletti nők 57,7\%-a alkalmaz megbízható fogamzásgátló módszert [4]. A hatékony, reverzibilis fogamzásgátlási lehetőségek palettájának jelentős részét jelenleg a nő által megvalósított módszerek, azon belül is a fogamzásgátló tabletták használata teszi ki $[2,3,5]$. Mindösszesen négyféle fogamzásgátló módszer sorolható fel, amely a férfiak által vagy közremúk ödésével valósul meg. Ezek a mütétes meddővé tétel, a férfi óvszer, a megszakításos védekezés és a naptármódszer [5]. A férfiak múvi meddővé tétele (vasectomia), hasonlóan a nók esetében végzett beavatkozáshoz (tubasterilizáció), végleges megoldásnak tekinthető. A vasectomia során mindkét ductus deferens folytonosságát megszüntetik, általában egy rész kimetszésével és a szabad végek lekötésével [6]. A mútétet követően három hónappal végzett kontrollspermiogram az esetek $80 \%$-ában a hím ivarsejtek teljes hiányát igazolja az ejakulátumban. A sikertelen mútétek aránya rendkívül alacsony, de amennyiben hat hónappal a vasectomia után még mindig motilis spermium látható az ondóban, a mútét ismétlése javasolt [7]. Magyarországon a mưvi meddővé tétel a jelenlegi jogi szabályozás szerint 40 éves kortól vagy három vér szerinti gyermek esetén végezhető el, leghamarabb az igény írásban való bejelentésétől számított 12 hónap múlva. A beavatkozás önköltséges. Míg a nyugat-európai országokban ötször annyi sterilizáció történik férfiaknál, mint nőknél, ez az arány Magyarországon lényegében fordított [8]. A páciensek közel 6\%-a ugyanakkor a későbbiekben a fertilitás visszaállítását kéri, amely mikrosebészeti módszerekkel $89 \%$-ban meg is valósítható [9]. A férfiak számára a biztonságos, de nem végleges fogamzásgátlási megoldás lényegében az óvszer használatában merül ki. A fejlett országokban az óvszerrel való védekezés aránya összességében $20-47 \%$ közötti [3], párkapcsolatban élő férfiak esetében pedig régiótól függően 0,8-24,1\% között [5] mozog, annak ellenére, hogy a férfiak 48-63\%-ának véleménye szerint az óvszer csökkenti a szexuális elégedettséget [10]. Ebből kifolyólag egyértelmú az igény a férfi által alkalmazható egyéb lehetôségek kifejlesztésére. Ezt támasztják alá korábbi vizsgálatok is, amelyek alapján a férfiak $44-83 \%$-a szívesen használna férfi fogamzásgátló tablettát [10].

\section{A férfi hormonális fogamzásgátlás fiziológiája}

A hypothalamus gonadotropin-releasing hormon (GnRH) pulzatilis kiválasztása stimulálja az agyalapi mirigy folliculusstimuláló hormon (FSH) és luteinizáló hormon (LH) termelését. Ez a két gonadotropin hormon szabályozza a here Leydig-sejtjeinek tesztoszteron(TE-) szintézisét és a Sertoli-sejteken keresztül a hím ivarsejtek képzését. A keletkező TE 1\%-a ösztradiollá metabolizálódik az aromatáz enzim hatására, illetve további 1\%-ból az 5-alfa-reduktáz közremúködésével 5-alfa-dihidrotesztoszteron (DHT) keletkezik, amely igen hatékony androgén [11]. A Leydig-sejtek magas, a szérumban mérhetőnél akár 100-szor magasabb intratesticularis TE-koncentrációt biztosítanak, amely esszenciális a spermiogenezis szempontjából. A hereszöveten belüli magas ösztradiol- és DHT-koncentráció szintén hozzájárulhat a hím ivarsejtek élettani termelődéséhez [11].

A férfi hormonális fogamzásgátlás alapja az agyalapi mirigy gonadotropin szekréciójának gátlása, amely külsőleg adott szteriodhormonokkal (elsősorban TE-vel) valósítható meg. Az FSH és LH termelődésének csökkentése a here-TE és ezáltal a hím ivarsejt termelésének jelentős csökkenését vonja maga után, amely alkalmas lehet a kívánt fogamzásgátló hatás elérésére. Hasonlóképpen a nőknél alkalmazott hormonális módszerekhez, a férfiak esetében is egy hatékony, reverzibilis, mellékhatásait tekintve biztonságos gyógyszer kifejlesztése a kívánatos. Ugyanakkor figyelembe kell venni, hogy a herék 
spermiumtermelése folyamatos, a spermiumok képződési ideje nagyjából 72 nap. Ebból az következik, hogy a külsőleg adagolt hormonkezelés fogamzásgátló hatásának kialakulása minimum két-három hónapot vesz igénybe [11]. A fogamzásgátlás során az ideális cél az azoospermiás állapot elérése, amely azt jelenti, hogy nincs spermium az ejakulátumban.

\section{Megalapozó klinikai vizsgálatok tesztoszteron-enantát (TE-EN) hatóanyaggal}

A férfi hormonális fogamzásgátlás klinikai vizsgálatai az 1970-es években indultak az Amerikai Egyesült Államokban. Ezekben a korai időszakokban a TE észterizált származékával, az intramuscularis injekció formájában adagolható TE-EN adásával igyekeztek a here spermiumtermelését gátolni. A problémakört felkarolva, az 1990-es években az Egészségügyi Világszervezet (WHO) két, multicentrikus tanulmányt indított a TE-EN hatékonyságának vizsgálatára. Az első tanulmány során a résztvevők heti $200 \mathrm{mg}$ TE-EN kezelésben részesültek intramuscularis injekció formájában [12]. A hat hónapos bevezető kezelés alatt a férfiak 65\%-ánál a spermiumok eltüntek az ejakulátumból, az azoospermia kialakulása után a pácienseknél egy éven keresztül a kezelést tovább folytatták egyéb védekezési forma nélkül. A módszer Pearl-indexe (az egy év alatt létrejövő terhességek száma 100, rendszeres szexuális életet élő pár esetében az adott fogamzásgátlási módszer alkalmazásával) 0,8-nek bizonyult [12]. Összehasonlításképpen: a kombinált hormontartalmú női fogamzásgátló tabletták hiba nélküli használat esetén 0,62-1,26 Pearl-indexszel rendelkeznek. A második WHO-tanulmány során a párok már akkor is a vizsgálat egyéb védekezés nélküli fázisába léphettek, amikor a férfi ejakulátumában a spermiumkoncentráció 5 millió/ml, majd a tanulmány későbbi szakaszában 3 millió/ml alá csökkent [13]. Ez önmagában is jelentős méretű csökkenésnek tekinthető, mivel az átlagos spermiumkoncentráció 73 millió/ml körül mozog. A vizsgálatot kilenc ország 15 kutatócentrumában végezték, és magyar vonatkozásként említhető meg, hogy a vizsgálat kivitelezésében a Szegedi Tudományegyetem, Szülészeti és Nőgyógyászati Klinika Andrológia szakrendelése is részt vett. Azon férfiak csoportjában, ahol a spermiumkoncentráció 3 millió/ml alá csökkent, a Pearl-index 8,1 volt, míg az azoospermiát elérô csoportban terhesség nem fordult elő. A kombinált Pearlindex a vizsgált populációra nézve így 1,4-nek adódott [13]. Az azoospermiát eléró páciensek aránya nagyobb volt az ázsiai rasszba tartozó férfiak körében a többi rasszbeli férfiakhoz viszonyítva $(95 \%$ vs. $68 \%$; $<<0,001)$. Összegzésként elmondható, hogy a nyert adatok jó alapot szolgáltattak a tesztoszteronszármazékok esetleges férfi fogamzásgátlóként való felhasználására, de a széles körü használat szempontjából számos probléma merült fel: egyrészt a férfiak 77\%-ánál alakult ki csak tartósan azoospermia, a fennmaradó 23\%-nál nem, és ebben a csoportban a fogamzásgátló hatás nem volt kielégítő. Másrészt a széles felhasználás további akadálya az alkalmazás módja, hiszen hetente adott intramuscularis injekcióról van szó, illetve a gyakorlatban figyelembe kell venni, hogy az azoospermia kialakulása a kezelés elkezdése után két-három hónappal jelentkezik, amely egyébként a vasectomia után tapasztaltaknak megfelel [13].

A további vizsgálatok egyik célja olyan alkalmazási módok fejlesztése volt, amelyek nem igénylik a hetente adott intramuscularis adagolást. Egy tanulmány során az azoospermia vagy súlyos oligozoospermia (spermiumkoncentráció <l millió/ml) eléréséhez 800, illetve 1200 mg TE-EN tartalmú implantátumot helyeztek háromhavonta kaukázusi rasszba tartozó férfiak alhasának bőre alá [14]. Sajnos, az eredmények a korábbi WHO-tanulmányokhoz képest javulást nem mutattak. Amennyiben a spermiumtermelés gátlása megvalósult, terhesség nem fordult elő. Ugyanakkor az implantátumok kilökődését tapasztalták az esetek 10\%-ában, amely más, szintén implantátumok alkalmazásával végzett vizsgálatokban is megközelítőleg hasonló arányt mutatott $[14,15]$.

Előzetes felmérések alapján a férfiak egy része a szájon keresztül szedhető fogamzásgátló tablettákat részesítené előnyben [16]. Ismert, hogy a per os alkalmazott TE és származékai a májban jelentôs mértékü first-pass effektuson mennek keresztül, így a biológiai hatásuk jelentős mértékben csökken. Emiatt olyan új formulák fejlesztése indult el, amelyek fokozzák a TE hatóanyag gastrointestinalis nyirokrendszeren keresztül történő felszívódását, ezáltal az azonnali metabolizáció elkerülhető [17].

A transdermalis gél vagy tapasz formájában elérhető TE-tartalmú hormonpótló készítmények fogamzásgátlás céljára, sajnos, önmagukban nem elégségesek, mert súlyos oligozoospermia (<1 millió/ml) csak a páciensek 24\%-ánál alakul ki [18]. Ennek oka alapvetően az LH- és FSH-termelődés elégtelen mértékű gátlása. Ugyanakkor a tapasz vagy a gél egy gesztagén vegyülettel alkalmazva ígéretes kombinációt jelenthet. A TE-EN hatóanyaggal végzett jelentősebb tanulmányok eredményeit foglalja össze az 1. táblázat.

\section{Tesztoszteron-undekanoát (TE-UN)}

A hetente alkalmazott injekciók kiváltásának másik lehetőségét kínálta a TE-UN, amelynek farmakokinetikai jellemzői kedvezőbbnek bizonyultak. Az 500 mg hatóanyag-tartalmú depot injekció formájában minimum hat, de átlagosan 8-12 hetes időközönkénti adagolással is megfelelő szérumszint biztosítható [19]. Mivel a korábbi, TE-EN-nel végzett vizsgálatok során az ázsai rasszba tartozó férfiak között kiugró arányban értek el azoospermiát, érthető, hogy kínai kutatók további nagy esetszámú vizsgálatokat indítottak. Egy multicentrikus kutatás során kezdeti $1000 \mathrm{mg}$, majd havonta adott 500 mg TE-UN injekciókkal azoospermia, vagy 3 millió 
1. táblázat | Tesztoszteron-enantáttal végzett fóbb tanulmányok eredményei

\begin{tabular}{l|l|l|l|l|l}
\hline Tanulmány & Hatóanyag és adagolás & $\begin{array}{l}\text { Bevont férfiak } \\
\text { száma }\end{array}$ & $\begin{array}{l}\text { Spermiumkoncentrá- } \\
\text { ció célértéke }\end{array}$ & $\begin{array}{l}\text { Célérték tartós elérésének } \\
\text { sikertelenségi aránya }\end{array}$ & Pearl-index \\
\hline WHO, $1990[12]$ & $\begin{array}{l}200 \mathrm{mg} \text { tesztoszteron-enantát im. } \\
\text { hetente }\end{array}$ & 271 & Azoospermia & $31,4 \%$ & 0,8 \\
\hline WHO, $1996[13]$ & $\begin{array}{l}200 \mathrm{mg} \text { tesztoszteron-enantát im. } \\
\text { hetente }\end{array}$ & 399 & $<3$ millió/ml & $3,3 \%$ & 2,8 \\
\hline $\begin{array}{l}\text { McLachlan, 2000 } \\
{[14]}\end{array}$ & $\begin{array}{l}800 \mathrm{mg} \text { vagy } 1200 \mathrm{mg} \text { tesztoszte- } \\
\text { ron-enantát tartalmú implantátum } \\
+5 \mathrm{mg} \text { finasterid }\end{array}$ & 36 & $<1$ millió/ml & $28 \%$ & Nem kalkulált \\
\hline
\end{tabular}

im. = intramuscularis adagolás; Pearl-index = az egy év alatt létrejövő terhességek száma 100, rendszeres szexuális életet élő pár esetében az adott fogamzásgátlási módszer alkalmazásával

2. táblázat | Tesztoszteron-undekanoáttal végzett fóbb tanulmányok eredményei

\begin{tabular}{|c|c|c|c|c|c|}
\hline Tanulmány & Hatóanyag és adagolás & $\begin{array}{l}\text { Bevont férfiak } \\
\text { száma }\end{array}$ & $\begin{array}{l}\text { Spermiumkoncentrá- } \\
\text { ció célértéke }\end{array}$ & $\begin{array}{l}\text { Célérték tartós elérésének } \\
\text { sikertelenségi aránya }\end{array}$ & Pearl-index \\
\hline $\mathrm{Gu}, 2003[20]$ & $\begin{array}{l}1000 \text { mg tesztoszteron-undekanoát, } \\
\text { majd havonta } 500 \mathrm{mg} \mathrm{im.}\end{array}$ & 308 & $<3$ millió $/ \mathrm{ml}$ & $5,2 \%$ & 2,3 \\
\hline $\mathrm{Gu}, 2009[21]$ & $\begin{array}{l}1000 \mathrm{mg} \text { tesztoszteron-undekanoát, } \\
\text { majd havonta } 500 \mathrm{mg} \text { im. }\end{array}$ & 1045 & $<1$ millió/ml & $6,1 \%$ & 1,1 \\
\hline
\end{tabular}

im. = intramuscularis adagolás; Pearl-index = az egy év alatt létrejövő terhességek száma 100, rendszeres szexuális életet élő pár esetében az adott fogamzásgátlási módszer alkalmazásával

spermium/ml alatti oligozoospermia kialakulását célozták meg, és ezt követően vizsgálták a fogamzásgátlás hatékonyságát [20]. A tanulmány során a páciensek 2,9\%ában nem jött létre súlyos oligozoospermia vagy azoospermia, míg 2,3\%-ban a célértéket a hímivarsejtkoncentráció kezdetben elérte, de azt követően ismét a kívánt szint fölé emelkedett. Így az összes vizsgált páciens tekintetében a biztonságos fogamzásgátlási szint elérése 5,2\%-ban bizonyult sikertelennek [20]. Egy későbbi, több mint ezer kínai férfi bevonásával végzett kutatás során szintén havonta intramuscularisan adott $500 \mathrm{mg}$ TE-UN fogamzásgátló hatékonyságát vizsgálták hat hónapos szuppressziós időszak után 24 hónapos időintervallumban. Az elérni kívánt spermiumkoncentráció célértékét l millió/ml vagy az alatti koncentrációban határozták meg [21]. A férfiak 4,8\%-ában ezt a célértéket elérni nem sikerült, illetve $1,3 \%$-ban a spermiumkoncentráció a kezdeti gáltás után ismét a célként meghatározott érték fölé emelkedett. Ezek alapján a módszer sikertelensége az összes résztvevőt tekintve 6,1\%-nak bizonyult [21]. A 24 hónapos hatékonysági fázisban (tehát azokat a pácienseket nem számolva, akiknél az oligozoospermia nem alakult ki) a módszer Pearl-indexe 1,1-nek bizonyult [21]. A gyakorlati alkalmazás szempontjából szintén fontos, hogy a spermium-célkoncentrácó elérése átlagosan 108 napot vett igénybe.

A TE-UN hatóanyaggal végzett fóbb tanulmányok eredményeit a 2. táblázat foglalja össze.

\section{TE és egyéb hatóanyag-kombinációk}

Bár ázsiai férfiakban a csak tesztoszteronszármazékot alkalmazó fogamzásgátlási módszerek magas (90-98\%) arányban érnek el súlyos oligozoospermiás vagy azoospermiás állapotot, ez a kaukázusi rasszba tartozó férfiak esetében (60-70\%) közel sincs így. Ennek a különbségnek a pontos oka jelenleg még nem teljesen ismert. Emiatt a későbbi vizsgálatok további célja olyan gyógyszerkombinációk kifejlesztése volt, amelyek segítségével az azoospermiás férfiak aránya, így a fogamzásgátló módszer megbízhatósága ebben a populációban is növelhetővé vált.

Egyik lehetőségként a TE kiegészítéseként ösztradiol alkalmazása merült fel. A vizsgálati eredmények alapján az ösztradiol alacsony dózisban nem fokozta a gonadotropinszekréció gátlását, míg magasabb dózisokban jelentősen megnőtt a nem kívánt mellékhatások aránya [22]. Az igen szúk terápiás tartomány és bizonytalan hatás miatt az ösztradiol alkalmazását korán elvetették [22].

Másik lehetôségnek a TE-gesztagén kombináció adódott, mivel bizonyos gesztagénszármazékok androgénreceptorokhoz kötődve antiandrogén hatással bírnak, így a megmaradt intratesticularis androgén funkció további csökkentéséhez hozzájárulhatnak [23]. Az antiandrogén jelleg mellett a gesztagének a GnRH-pulzáció csökkentésével az LH-termelődés gátlásán keresztül is hozzájárulhatnak a fogamzásgátló hatás erősítéséhez. Az elmúlt időszakban számos vegyület hatékonyságát vizs- 
gálták. In vitro és in vivo állatkísérletekben a levonorgestrel és a norethindron-acetát hasonló mértékű androgénagonista hatást mutatott, a cyproteron-acetát alacsony dózisban androgénantagonistaként, magasabb dózisban androgénagonistaként viselkedett. A nestoron esetében lényegi androgénhatás nem volt kimutatható [23]. Az LH-szuppressziós hatás tekintetében a levonorgestrel és másodsorban a norethindron-acetát dózisfüggően, magasabb koncentrációknál gátolta az LH-termelődést, míg a cyproteron-acetát és nestoron esetében a kísérleti állatok LH-termelése növekedést mutatott [23].

\section{TE + levonorgestrel (LNG)}

Az LNG kifejezett gonadotropinszekréció-gátló hatással bír, amely közel egyenértékű a referenciaként is használt cyproteron-acetát hatásával [24]. A klinikai vizsgálatok eredménye alapján a TE mellé adagolt LNG növelte a súlyos oligozoospermia vagy azoospermia kialakulásának esélyét a csak TE-vel végzett szuppresszióhoz képest, ugyanakkor a kezelés így is a férfiak közel 6-10\%-ában elégtelennek bizonyult [15, 25]. Mellékhatásként a pácienseknél nem kívánt súlynövekedés jelentkezett, amely az LNG dózisának csökkentésével, a spermiogenezis gátlásának megtartása mellett, kiküszöbölhetővé vált [26]. LNG-tartalmú implantátum (Norplant II) és intramuscularisan adott TE-EN alkalmazásával minden páciens esetén sikerült a spermiumtermelést 1 millió $/ \mathrm{ml}$ alá szorítani, de ezzel a módszerrel az implantátum és a hetente adott injekció okozta kényelmetlenségek megmaradtak [18]. Sajnos, amennyiben ebben a kombinációban TE-tapaszt vagy per os szedhetô LNG-t alkalmaztak, a spermiogenezis gátlása elégtelennek bizonyult [18]. A TE-LNG kombinációval végzett tanulmányok eredményeit a 3. táblázat szemlélteti.

\section{$\mathrm{TE}+$ etonogestrel/desogestrel (ET)}

A desogestrel metabolitjaként ismert ET férfi fogamzásgátlóként kombinációban való alkalmazását a vegyület relatíve alacsony mértékű androgénhatása indokolhatja. A kutatások egy része napi rendszerességgel szedett ET[27] vagy desogestrel- [28] tablettákat vizsgált, míg más tanulmányok ET-tartalmú implantátumot kombináltak TE-származékkal. Az ET-tartalmú implantátum női hormonális fogamzásgátlás céljából egyébként is a világ számos országában elérhető. Két, nagyobb esetszámú tanulmány során vizsgálták a kombináció hatását a hímivarsejt-termelésre [29, 30]. Tesztoszteron-dekanoát és ET-tartalmú implantátum alkalmazásakor a TE adagolási sémájától függően 48 hét alatt 93,5-100\%-ban lehetett 3 millió/ml alatti spermiumkoncentrációt elérni [29]. Figyelemre méltó adat azonban, hogy a bevont férfiak 10,8\%-a a vizsgálatban való részvételt valamilyen szövődmény vagy mellékhatás miatt idő előtt megszakította. Ilyen nemkívánatos esemény volt például a merevedési

3. táblázat | Tesztoszteron és levonorgestrel kombinációval végzett főbb tanulmányok eredményei

\begin{tabular}{|c|c|c|c|c|}
\hline Tanulmány & Hatóanyag és adagolás & $\begin{array}{l}\text { Bevont férfiak } \\
\text { száma }\end{array}$ & $\begin{array}{l}\text { Spermiumkoncentráció } \\
\text { célértéke }\end{array}$ & $\begin{array}{l}\text { Célérték tartós elérésének } \\
\text { sikertelenségi aránya }\end{array}$ \\
\hline Bebb, $1996[25]$ & $\begin{array}{l}100 \mathrm{mg} \text { tesztoszteron-enantát hetente im. } \\
+0,5 \mathrm{mg} \text { levonorgestrel naponta per os }\end{array}$ & 18 & $<3$ millió $/ \mathrm{ml}$ & $6 \%$ \\
\hline \multirow[t]{5}{*}{ Gonzalo, 2002 [18] } & \multirow[t]{2}{*}{$10 \mathrm{mg}$ tesztoszterontapasz (Testoderm) naponta } & \multirow[t]{2}{*}{19} & Azoospermia & $76 \%$ \\
\hline & & & $<1$ millió/ml & $76 \%$ \\
\hline & $\begin{array}{l}10 \mathrm{mg} \text { tesztoszterontapasz (Testoderm) naponta } \\
\text { + } 300 \mathrm{mg} \text { levonorgestrelimplantátum (Norplant II) } \\
(144-196 \mu \mathrm{g} \text { levonorgestrelfelszabadulás/nap) }\end{array}$ & 20 & $\begin{array}{l}\text { Azoospermia } \\
<1 \mathrm{millió} / \mathrm{ml}\end{array}$ & $\begin{array}{l}65 \% \\
40 \%\end{array}$ \\
\hline & $\begin{array}{l}10 \mathrm{mg} \text { tesztoszterontapasz (Testoderm) naponta } \\
+125 \mu \mathrm{g} \text { levonorgestrel per os }\end{array}$ & 15 & $\begin{array}{l}\text { Azoospermia } \\
<1 \mathrm{millió} / \mathrm{ml}\end{array}$ & $\begin{array}{l}67 \% \\
58 \%\end{array}$ \\
\hline & $\begin{array}{l}100 \mathrm{mg} \text { tesztoszteron-enantát im. hetente } \\
\text { + } 300 \mathrm{mg} \text { levonorgestrelimplantátum (Norplant II) } \\
(144-196 \mu \mathrm{g} \text { levonorgestrelfelszabadulás/nap) }\end{array}$ & 14 & $\begin{array}{l}\text { Azoospermia } \\
<1 \mathrm{millió} / \mathrm{ml}\end{array}$ & $\begin{array}{l}7 \% \\
0 \%\end{array}$ \\
\hline \multirow[t]{6}{*}{ Anawalt, 2005 [26] } & \multirow{3}{*}{$\begin{array}{l}100 \mathrm{mg} \text { tesztoszteron-enantát hetente im. } \\
+0,031 \mathrm{mg} \text { levonorgestrel naponta per os }\end{array}$} & \multirow[t]{3}{*}{20} & Azoospermia & $40 \%$ \\
\hline & & & $<1$ millió $/ \mathrm{ml}$ & $15 \%$ \\
\hline & & & $<3$ millió $/ \mathrm{ml}$ & $10 \%$ \\
\hline & \multirow{3}{*}{$\begin{array}{l}100 \mathrm{mg} \text { tesztoszteron-enanthát hetente im. } \\
+0,062 \mathrm{mg} \text { levonorgestrel naponta per os }\end{array}$} & \multirow[t]{3}{*}{21} & Azoospermia & $38 \%$ \\
\hline & & & <l millió/ml & $9 \%$ \\
\hline & & & $<3$ millió/ml & $5 \%$ \\
\hline Wang, 2006 [15] & $\begin{array}{l}200 \text { mg tesztoszterontartalmú + levonorgestreltar- } \\
\text { talmú implantátum }\end{array}$ & 41 & $<1$ millió/ml & $10 \%$ \\
\hline
\end{tabular}

im. = intramuscularis adagolás 
zavar megjelenése, agresszív reakciók előfordulása, az implantátum behelyezésével kapcsolatos komplikáció, érzelmi labilitás kialakulása, de laringitis és myocarditis is előfordult a páciensek körében [29]. Hasonló arányú (9\%) volt az idő előtti kilépés a másik, intramuscularisan adagolt TE-UN-t és ET-t kibocsátó implantátumot használó tanulmányban is [30], ahol adagolási sémától függően 42-44 hét alatt 95-100\%-ban értek el 3 millió/ml alatti

4. táblázat | Tesztoszteron és etonogestrel/desogestrel kombinációval végzett főbb tanulmányok eredményei

\begin{tabular}{|c|c|c|c|c|}
\hline Tanulmány & Hatóanyag és adagolás & $\begin{array}{l}\text { Bevont férfiak } \\
\text { száma }\end{array}$ & $\begin{array}{c}\text { Spermiumkoncentráció } \\
\text { célértéke }\end{array}$ & $\begin{array}{c}\text { Célérték tartós elérésének } \\
\text { sikertelenségi aránya }\end{array}$ \\
\hline \multirow[t]{6}{*}{ Anawalt, 2000 [28] } & \multirow{2}{*}{$\begin{array}{l}50 \mathrm{mg} \text { tesztoszteron-enantát im. hetente } \\
+150 \mu \mathrm{g} \text { desogestrel per os naponta }\end{array}$} & \multirow[t]{2}{*}{9} & Azoospermia & $43 \%$ \\
\hline & & & $<1$ millió/ml & $33 \%$ \\
\hline & \multirow{2}{*}{$\begin{array}{l}100 \mathrm{mg} \text { tesztoszteron-enantát im. hetente } \\
+150 \mu \mathrm{g} \text { desogestrel per os naponta }\end{array}$} & \multirow[t]{2}{*}{7} & Azoospermia & $0 \%$ \\
\hline & & & $<1$ millió/ml & $0 \%$ \\
\hline & \multirow{2}{*}{$\begin{array}{l}100 \mathrm{mg} \text { tesztoszteron-enantát im. hetente } \\
+300 \mu \mathrm{g} \text { desogestrel per os naponta }\end{array}$} & \multirow[t]{2}{*}{8} & Azoospermia & $12 \%$ \\
\hline & & & <l millió/ml & $12 \%$ \\
\hline \multirow[t]{6}{*}{ Hay, 2005 [27] } & \multirow{3}{*}{$\begin{array}{l}400 \mathrm{mg} \text { tesztoszteron-dekanoát im. négyhetente } \\
+300 \mu \mathrm{g} \text { etonogestrel per os naponta }\end{array}$} & \multirow[t]{3}{*}{55} & Azoospermia & $4,7 \%$ \\
\hline & & & $<1$ millió/ml & $0 \%$ \\
\hline & & & $<3$ millió $/ \mathrm{ml}$ & $0 \%$ \\
\hline & \multirow{3}{*}{$\begin{array}{l}400 \mathrm{mg} \text { tesztoszteron-dekanoát im. hathetente } \\
+300 \mu \mathrm{g} \text { etonogestrel per os naponta }\end{array}$} & \multirow[t]{3}{*}{57} & Azoospermia & $17,5 \%$ \\
\hline & & & $<1$ millió/ml & $2,5 \%$ \\
\hline & & & $<3$ millió $/ \mathrm{ml}$ & $0 \%$ \\
\hline \multirow[t]{9}{*}{ Brady, 2006 [29] } & \multirow{3}{*}{$\begin{array}{l}400 \mathrm{mg} \text { tesztoszteron-dekanoát im. négyhetente } \\
\text { + } 204 \mathrm{mg} \text { etonogestrelimplantátum }\end{array}$} & \multirow[t]{3}{*}{42} & Azoospermia & $19,4 \%$ \\
\hline & & & $<1$ millió $/ \mathrm{ml}$ & $6,5 \%$ \\
\hline & & & $<3$ millió/ml & $6,5 \%$ \\
\hline & \multirow{3}{*}{$\begin{array}{l}400 \mathrm{mg} \text { tesztoszteron-dekanoát im. hathetente } \\
+204 \mathrm{mg} \text { etonogestrelimplantátum }\end{array}$} & \multirow[t]{3}{*}{51} & Azoospermia & $22,5 \%$ \\
\hline & & & $<1$ millió $/ \mathrm{ml}$ & $0 \%$ \\
\hline & & & $<3$ millió $/ \mathrm{ml}$ & $0 \%$ \\
\hline & \multirow{3}{*}{$\begin{array}{l}600 \mathrm{mg} \text { tesztoszteron-dekanoát im. hathetente } \\
+204 \mathrm{mg} \text { etonogestrelimplantátum }\end{array}$} & \multirow[t]{3}{*}{37} & Azoospermia & $15,2 \%$ \\
\hline & & & $<1$ millió/ml & $6,1 \%$ \\
\hline & & & $<3$ millió/ml & $6,1 \%$ \\
\hline \multirow{18}{*}{$\begin{array}{l}\text { Mommers, } 2008 \\
{[30]}\end{array}$} & \multirow{3}{*}{$\begin{array}{l}750 \text { mg tesztoszteron-undekanoát im. } 12 \text { hetente } \\
\text { + } 178 \text { mg lassú kibocsátású etonogestrelimplantá- } \\
\text { tum }\end{array}$} & \multirow[t]{3}{*}{47} & $<0,1$ millió $/ \mathrm{ml}$ & $19 \%$ \\
\hline & & & $<1$ millió $/ \mathrm{ml}$ & $11 \%$ \\
\hline & & & $<3$ millió $/ \mathrm{ml}$ & $4 \%$ \\
\hline & \multirow{3}{*}{$\begin{array}{l}750 \text { mg tesztoszteron-undekanoát im. } 10 \text { hetente } \\
\text { + } 178 \text { mg lassú kibocsátású etonogestrelimplantá- } \\
\text { tum }\end{array}$} & \multirow[t]{3}{*}{50} & $<0,1$ millió $/ \mathrm{ml}$ & $16 \%$ \\
\hline & & & $<1$ millió/ml & $10 \%$ \\
\hline & & & $<3$ millió $/ \mathrm{ml}$ & $3 \%$ \\
\hline & \multirow{3}{*}{$\begin{array}{l}1000 \text { mg tesztoszteron-undekanoát im. } 12 \text { hetente } \\
\text { + } 178 \text { mg lassú kibocsátású etonogestrelimplantá- } \\
\text { tum }\end{array}$} & \multirow[t]{3}{*}{51} & $<0,1$ millió $/ \mathrm{ml}$ & $15 \%$ \\
\hline & & & <l millió/ml & $5 \%$ \\
\hline & & & $<3$ millió $/ \mathrm{ml}$ & $3 \%$ \\
\hline & \multirow{3}{*}{$\begin{array}{l}750 \text { mg tesztoszteron-undekanoát im. } 12 \text { hetente } \\
\text { + } 144 \text { mg gyors kibocsátású etonogestrelimplantá- } \\
\text { tum }\end{array}$} & 50 & $<0,1$ millió $/ \mathrm{ml}$ & $22 \%$ \\
\hline & & & $<1$ millió/ml & $8 \%$ \\
\hline & & & $<3$ millió/ml & $5 \%$ \\
\hline & $750 \mathrm{mg}$ tesztoszteron-undekanoát im. 10 hetente & 50 & $<0,1 \mathrm{millió} / \mathrm{ml}$ & $6 \%$ \\
\hline & $\begin{array}{l}\text { + } 144 \text { mg gyors kibocsatasu etonogestrelimplanta- } \\
\text { tum }\end{array}$ & & <l millió/ml & $0 \%$ \\
\hline & & & $<3$ millió/ml & $0 \%$ \\
\hline & $750 \mathrm{mg}$ tesztoszteron-undekanoát im. 10 hetente & 49 & $<0,1 \mathrm{millió} / \mathrm{ml}$ & $2 \%$ \\
\hline & $\begin{array}{l}\text { + } 144 \text { mg gyors kibocsátású etonogestrelimplantá- } \\
\text { tum }\end{array}$ & & $<1 \mathrm{millió} / \mathrm{ml}$ & $0 \%$ \\
\hline & & & $<3$ millió/ml & $0 \%$ \\
\hline
\end{tabular}

im. = intramuscularis adagolás 
spermiumkoncentrációt [30]. A szájon keresztül alkalmazott ET és intramuscularis tesztoszteron-dekanoát kombináció használata során a vizsgálatot a páciensek 21\%-a szakította meg idő előtt, elsősorban nem kívánt mellékhatások miatt [27]. Az alkalmazott kombinációtól függően a férfiak 60 , illetve $77 \%$-a volt elégedett a fogamzásgátlás ezen módszerével [27]. A TE-ET kombinációval végzett tanulmányok eredményeit a 4. táblázat prezentálja.

\section{TE + nestoron (NES)}

A NES az egyik leghatékonyabb gesztagénszármazék, amelynek szinte nincs androgénaktivitása, ugyanakkor a gonadotropin hormonok elválasztására erőteljes gátlóhatással bír. Ezen kedvező farmakológiai jellemzők és a lehetséges mellékhatások enyhe mértéke miatt ígéretes kutatási eredmények láttak napvilágot az elmúlt időszakban. Transdermalis TE-gél és ugyancsak gél formájában alkalmazott NES napi használatával 24 hét után a férfiak 88,5\%-ánál sikerült a spermiumkoncentrációt 1 millió/ $\mathrm{ml}$ alá szorítani [31]. Egy felmérésben a férfiak 58\%-a volt elégedett a két hatóanyag gélként való alkalmazásával, és a férfiak 34\%-a használná a transdermalis gélt elsődleges fogamzásgátlási módszerként [32]. A készítmény továbbfejlesztése jelenleg is folyamatban van, de széles körü használatát továbbra is nehezíti azon férfiak viszonylagosan magas aránya (11-12\%), akiknél a spermiumkoncentráció célértékét $(<\mathrm{l}$ millió/ml), így az elfogadható Pearl-indexet nem sikerült elérni. A spermiogenezis gátlásának sikertelensége, sajnos, csak a gél 24 hétig tartó alkalmazását követően derül ki, így célszerúnek tünik az ilyen, nem megfelelően reagáló páciensek hamarabbi kiszűrése a felesleges kezelés elkerülése érdekében. A transdermalis TE és NES kombinációval végzett tanulmány során [31] a kezelés negyedik hetében mért LH- és FSH-szérumszint 97\%-os szenzitivitással, de csak 63\%-os specificitással tudta előre jelezni a spermiumcélérték elérésének sikertelenségét [33].

\section{TE + norethisteron-enantát (NETE)}

A férfi hormonális fogamzásgátlás fejlesztésének folyamatában jelentős szerepet kapott a TE-UN és NETE kombinációjával végzett tanulmány, amely rávilágított a hormonális kezelés potenciális veszélyeire [34]. A tanulmány során 320 férfit vontak be a kezelésbe, akiknek 95,9\%-a 24 hét után elérte a célként meghatározott 1 millió/ml alatti spermiumkoncentrációs tartományt. A kombináció Pearl-indexe 2,18-nak adódott. Ugyanakkor az igen frekvensen előforduló mellékhatások miatt a tanulmányt félbe kellett szakítani. Több mint 38\%-ban számoltak be növekvő libidóról, 25\%-ot meghaladta a hangulati változások aránya, míg középsúlyos vagy súlyos depresszió 2,8, illetve agresszió 1,9\%-ban fordult eló [34]. Ismert, hogy a kezelés kezdeti időszakában a páciensek szérum-TE-szintje átmenetileg a fiziológiás érték alá esik [35], majd a kezelés későbbi időszakában a NETE hatására a nemi hormont kötő globulin (SHBG) termelődése csökken, így a szabad TE szintje számottevő emelkedést mutat [35]. Ezen hormonális változások részben magyarázhatják a hangulati eltéréseket, így elképzelhető, hogy a kezelési protokoll módosításával ezeknek a mellékhatásoknak az előfordulása csökkenthetóvé válik [34].

\section{TE + depo medroxiprogeszteron-acetát (DMPA)}

A DMPA intramuscularisan adagolva jó és hosszan tartó fogamzásgátló hatással bír nók esetén, ezért kézenfekvő választás lehet a férfiak hormonális fogamzásgátlásában való alkalmazásra is. A TE transdermalis gél és intramuscularis DMPA használatával 90\%-ban volt elérhető súlyos oligozoospermia 24 hetes alkalmazási periódus alatt [36]. Figyelemre méltó, hogy ezzel a hatóanyag-kombinációval már a kezelés első időszakában a hím ivarsejt termelődésének kiemelkedően gyors ütemú csökkenését lehetett elérni [37]. TE-implantátum és intramuscularis DMPA adagolásával a kezelés első hónapjában a spermiumkoncentráció átlagos csökkenése 88\%-nak bizonyult, míg TE egyedüli alkalmazásával ez a csökkenés átlagosan csak 42\% körüli [37]. A NES, NETE és DMPA hatóanyagokkal végzett fóbb kutatások eredményeit az 5 . táblázat mutatja be.

\section{GnRH agonisták-antagonisták}

Bebizonyosodott, hogy a GnRH-agonisták a szekréció kezdeti megugrása miatt nem hatékonyak a spermiumtermelés gátlásában, míg a GnRH-antagonisták, azok közül is főleg a hosszú hatású gyógyszerekkel végzett kutatások változó eredményt hoztak [11]. Esetleges szerepük az azoospermia indukciójának gyorsításában merülhet fel [11], de egy TE és DMPA kombinációval végzett tanulmány során a kezelés kiegészítése a GnRHantagonista acyclinnel nem gyorsította a spermiogenezis gátlását és nem javította a spermium-célkoncentrációt elérő résztvevők arányát [36]. A GnRH-antagonisták használata egyelőre a klinikai kutatásokban való felhasználásra korlátozódik [38], bár új, per os alkalmazható hatóanyagok esetleg szerepet kaphatnak valamilyen fogamzásgátló kombinációban [11].

\section{Szintetikus androgének}

\section{Dimethandrolon-undekanoát (DMAU)}

A férfi hormonális fogamzásgátlás egyik fő kutatási területe olyan szintetikus vegyületek kifejlesztése, amelyeknek az erős androgén és gesztagén hatása megmarad, ugyanakkor az életideje hosszabb a hepatotoxicitas mértékének növekedése nélkül. További szempont termé- 
5. táblázat | Tesztoszteron és nestoron vagy norethisteron-enantát, vagy depo medroxiprogeszteron-acetát kombinációval végzett főbb tanulmányok eredményei

\begin{tabular}{|c|c|c|c|c|}
\hline Tanulmány & Hatóanyag és adagolás & $\begin{array}{l}\text { Bevont férfiak } \\
\text { száma }\end{array}$ & $\begin{array}{l}\text { Spermiumkoncentráció } \\
\text { célértéke }\end{array}$ & $\begin{array}{l}\text { Célérték tartós elérésének } \\
\text { sikertelenségi aránya }\end{array}$ \\
\hline Turner, 2003 [37] & $\begin{array}{l}800 \mathrm{mg} \text { depo tesztoszteronimplantátum négyha- } \\
\text { vonta }+300 \mathrm{mg} \text { depo medroxiprogeszteron-acetát } \\
\text { im. háromhavonta }\end{array}$ & 55 & $<1$ millióóml & $3,6 \%$ \\
\hline Page, $2006[36]$ & $\begin{array}{l}100 \mathrm{mg} \text { tesztoszterongél (Testim 1\%) naponta } \\
+300 \mathrm{mg} \text { depo medroxiprogeszteron-acetát im. } \\
\text { háromhavonta }\end{array}$ & 22 & $<1$ millió $/ \mathrm{ml}$ & $10 \%$ \\
\hline \multirow[t]{4}{*}{ Ilani, 2012 [31] } & \multirow{2}{*}{$\begin{array}{l}10 \mathrm{~g} \mathrm{l} \% \text { tesztoszterongél }(10 \mathrm{mg} \text { tesztoszteron }) \\
+800 \mu \mathrm{g} \text { nestorongél naponta }\end{array}$} & \multirow[t]{2}{*}{33} & Azoospermia & $22 \%$ \\
\hline & & & $<1$ millió/ml & $11 \%$ \\
\hline & \multirow{2}{*}{$\begin{array}{l}10 \mathrm{~g} \mathrm{l} \% \text { tesztoszterongél }(10 \mathrm{mg} \text { tesztoszteron }) \\
+1200 \mu \mathrm{g} \text { nestorongél naponta }\end{array}$} & \multirow[t]{2}{*}{34} & Azoospermia & $31 \%$ \\
\hline & & & $<1$ millió/ml & $12 \%$ \\
\hline Behre, 2016 [34] & $\begin{array}{l}1000 \mathrm{mg} \text { tesztoszteron-undekanoát im. } \\
+200 \mathrm{mg} \text { norethisteron-enantát im. nyolchetente }\end{array}$ & 320 & $<1$ millió $/ \mathrm{ml}$ & $4,1 \%$ (Pearl-index: 2,18$)$ \\
\hline
\end{tabular}

im. = intramuscularis adagolás; Pearl-index = az egy év alatt létrejövő terhességek száma 100, rendszeres szexuális életet élő pár esetében az adott fogamzásgátlási módszer alkalmazásával

szetesen egy kedvező mellékhatásprofil elérése is. Az ilyen vegyületek közül legkedvezőbb tapasztalatok a DMAU-val gyưltek össze, amely erős androgén- és gesztagénaktivitással rendelkezik, így igen hatékonyan gátolja az agyalapi mirigy gonadotropinszekrécióját [23]. A kedvező állatkísérletes eredményeket követően fázis I vizsgálat történt a készítmény per os alkalmazásával. Önkéntes férfiaknál emelkedő dózisban alkalmazták a vegyületet a tolerálhatóság, mellékhatások, a gonadotropinszekréció-gátlás mértékének meghatározására. Az eredmények tekintetében a DMAU hatékonyan gátolta a gonadotropinszekréciót, acnén kívül más mellékhatás nem jelentkezett, de figyelembe kell venni, hogy minden dózisból csak egy adag bevétele történt [39]. A gyakorlat szempontjából jelentős megfigyelés, hogy a tablettát étkezés közben kell bevenni, egyébként a felszívódása elégtelen. Fontos tulajdonsága a vegyületnek, hogy gátolja a szervezet ösztrogéntermelését is, amely a kiegyensúlyozott csontanyagcsere szempontjából, valamint a testzsírszabályozás tekintetében igen fontos. Emiatt lényeges lehet a hosszú távú alkalmazásnál a csontsưrűséggel, a szervezet zsírmetabolizmusával, illetve egyéb ösztrogéndependens mechanizmusokkal kapcsolatos nemkívánatos mellékhatások figyelembevétele [23].

\section{7- $\alpha$-metil-19-nortesztoszteron (MENT)}

A MENT egy másik szintetikus androgén, amely a szelektív androgénreceptor-modulátorok csoportjába sorolható. A vegyület jellemzője, hogy míg ellenáll az 5- $\alpha$-reduktáz enzim múködésének, az aromatáz enzim bontani tudja, így egy ösztrogénreceptort stimulálni képes metabolit képződik, amelynek következtében a férfi szervezet ösztrogéndependens mechanizmusai zavartalanok maradhatnak. Ezen feltételezett jellemzők megerősítésére azonban további in vivo vizsgálatok szükségesek [40]. Egy 35 férfit beválogató tanulmányban egy, kettő vagy négy darab MENT-tartalmú implantátumot helyeztek 6-12 hónapra a résztvevők bőre alá. Egy implantátum esetén egy páciensnél sem sikerült megfelelő oligozoospermiát elérni, míg két implantátum esetén csak 38\%-ban, négy implantátum esetén már 82\%-ban alakult ki oligozoospermia [40] hat hónap után. Egy év használat esetén a négy implantátumot kapott férfiak 100\%-ában a spermiumkoncentráció 3 millió/ml alá esett, az azoospermia aránya $83 \%$ volt. A kezelés egy éve során a herék térfogata a négyimplantátumos csoportban a kiindulási érték 56\%-ára csökkent, amely változás reverzibilisnek bizonyult, a kezelést követően két hónappal a hereméret a vizsgálat előtti érték 86\%-ára visszatért. A hatékonyság növelése érdekében a MENT-tartalmú implantátumot ET- vagy LNG-tartalmú implantátummal kombinálták [41]. Minden páciensnél a kezelés 12 . hetére a spermiumkoncentráció 1 millió/ml alá esett, de ezt követően növekedést mutatott, és a hím ivarsejtek koncentrációja lényegében normális értékre állt vissza [41]. A csalódást keltő eredmény hátterében a MENTimplantátum technikai problémája állt, mert a hatóanyag-leadás és így a hatásosság az idő teltével rohamos csökkenést mutatott. Ezek miatt a MENT-tartalmú implantátumokkal végzett vizsgálatok leálltak, de maga a vegyület a későbbiekben újra megjelenhet a férfi hormonális fogamzásgátlással kapcsolatos kutatások palettáján.

\section{A spermiogenezis gátlás alóli „szökése”}

Jelenleg a férfi hormonális fogamzásgátlás egyik legkomolyabb akadálya az a tapasztalat, hogy a férfiak egy részénél a spermiogenezis gátlása kielégítő módon nem következik be, vagy ha be is következik, egy idő után a hím ivarsejtek termelődése a gátlás alól „kiszökik”. A jelenség magyarázatát nehezíti, hogy minimális mértékben vagy nem találtak különbséget a gonadotropin hormonok szuppressziójának mértékében olyan férfiak eseté- 
ben, akiknél a spermiumtermelődés gátlása a kívánt szintet nem érte el, azokhoz a páciensekhez képest, akiknél az azoospermia viszont kialakult $[42,43]$. Szintén nem igazolódott különbség a Leydig-sejt-funkciót reprezentáló inzulinszerű faktor-3 (INSL-3) szérumkoncentrációiban a hormonális kezelésre megfelelően és elégtelenül reagáló férfiak esetében [37]. A kezelésre elégtelenül reagáló férfiak esetében, úgy túnik, hogy a gonadotropin hormonok szekréciójának teljes gátlása ellenére bizonyos szintú intratesticularis TE-produkció kimutatható, amely elegendő a spermiumok termelődéséhez [43]. Ezt egy humán tanulmányban is igazolták, amely során a herén belüli TE-koncentráció 95\%-os csökkenése ellenére a hím ivarsejtek termelődése egyes férfiak esetében megmaradt [43]. A vizsgálat során 20 férfi részesült kombinált TE + gesztagén fogamzásgátlásban, a gonadotropin hormonok, a szérum-TE, illetve az intratesticularis TEszintek mérése a kezelés 24. hetében történtek [43]. Nem volt szignifikáns különbség sem a vérben mért gonadotropinok és TE, sem a hereszövetben mért TE koncentrációi tekintetében azon férfiak között, akiknél súlyos oligozoospermia (<1 millió/ml) alakult ki, és azon férfiak között, akiknél a hímivarsejt-termelés gátlása elégtelennek bizonyult. Bár bizonyos adatok azt sugallták, hogy a hereszöveti DHT szerepet játszhat a spermiogenezisben, ebben a vizsgálatban az intratesticularis DHT-koncentráció szintúgy nem mutatott különbséget a két csoport között [43]. Felmerült az androgén receptorok érzékenységbeli különbsége, esetleg az androgénmetabolizmus vagy a here szerkezetének eltérése is. Igazolt, hogy a gonadotropinszekréció gátlásával egy időben adott ketokonazol az intratesticularis TE-szintet tovább csökkentheti az eredeti koncentráció körülbelül 1\%-ára [38]. Ezt a hatást a ketokonazol a here TE-szintézisében szerepet játszó 17,20-liáz enzim gátlása révén fejti ki, amely eredmény arra is bizonyíték, hogy a here tovább termel TE-t a gonadotropinszekréció megszúnése ellenére [38]. Állatkísérletes modellben felmerült, hogy a külsőleg bevitt, gonadotropinszekréció gátlásához használt fogamzásgátló androgén hatóanyag is hozzájárulhat a spermiogenezis fenntartásához [11]. Mindenesetre az eredmények előrevetíthetik, hogy a jövőbeni kutatások célpontja lehet az androgénszintézisben részt vevő enzimek szelektív gátlása.

\section{A férfi hormonális fogamzásgátlás mellékhatásai}

Az eddigi tanulmányok alapján a hormonális módszerek rövid távú mellékhatásai kellőképpen körvonalazódtak. Mind a testi, mind a pszichés mellékhatások viszonylag frekvens előfordulása állapítható meg. Leggyakrabban az enyhe-közepesen súlyos acnék megjelenéséról számoltak be. Szintén sokszor előforduló fizikális mellékhatásnak bizonyult a hormonális kezelés alatt jelentkező súlygyarapodás, amelynek mértéke valamelyest függött az alkalmazott hatóanyagtól. Általában a kezelés alatt a herék térfogatának szignifikáns csökkenése jelentkezett. Konzisztens eredménynek bizonyultak olyan laborparaméter-változások, mint a koleszterin és fóleg a HDLkoleszterin szintjének csökkenése, illetve a hemoglobinkoncentráció és a hematokrit értékének növekedése. Ugyanakkor egyelőre nem állnak rendelkezésre adatok a fogamzásgátló kezelés esetleges hosszú távú szív- és érrendszeri hatásairól vagy az egyéb szervrendszerekre gyakorolt hatásokról. Egyes, alkilcsoportot tartalmazó, per os alkalmazott tesztoszteronszármazékok mellékhatásaként hepatotoxicitas igazolódott. A pszichés mellékhatásokat tekintve a hangulati ingadozás, a depresszió, agresszió, libidócsökkenés vagy kóros megnövekedése jelentkeztek leggyakrabban. A harmadik csoportba a hormonkészítmények alkalmazási módszerével kapcsolatos mellékhatások tartoztak, úgymint az implantátumok kilökődése, sebgyulladás vagy az intramuscularisan adott injekciókkal kapcsolatos panaszok. Kezdetben külön figyelemmel kezelték a TE-kezelések hatását a prostata elváltozásaira, mivel elterjedt volt az a feltételezés, hogy a TE növelheti a prostata-hyperplasia és a prostata rosszindulatú daganatainak előfordulását. Ez a félelem a vizsgálatok során nem igazolódott, hiszen nem volt változás a prostataspecifikus antigén szintjében és nem jelentkeztek gyakrabban prostataspecifikus vagy egyéb urológiai panaszok a kezelt férfiaknál [44]. Az egyes hatóanyagokkal kapcsolatban megjelent mellékhatások listáját a 6 . táblázat foglalja össze.

\section{A hímivarsejt-termelődés és a fogamzóképesség helyreállása a hormonális fogamzásgátlás elhagyását követően}

Ugyanúgy, mint a nók esetében, a férfi hormonális fogamzásgátlás esetében is alapvető követelmény, hogy a módszer reverzibilis legyen. Minden hatóanyaggal végzett tanulmány során a kutatók nagy hangsúlyt fektettek ennek a kérdésnek a vizsgálatára. A kezdeti, TE-EN használatával végzett WHO-tanulmányok utánkövetése során a férfiak 64-84\%-ánál tért vissza a spermiumkoncentráció az abban az időben a normálérték alsó határának tekintett 20 millió/ml szintre és 34-46\%-uknál a tanulmány előtti saját alapszintre [12, 13]. A 20 millió/ ml értéket az azoospermiás férfiak 111-112 nap alatt érték el, míg a saját alapszintet 201-203 nap alatt. Ezek az időintervallumok konzisztensek voltak mindkét WHOtanulmány során [12, 13]. A fogamzásgátlás alkalmazásának ideje alatt és az utánkövetési időben fogant és megszületett újszülötteknél rendellenesség nem igazolódott [13]. Egy, a hímivarsejt-termelődés regenerációját felmérő összefoglaló tanulmány során, több mint 1500 résztvevő adatait áttekintve, számos olyan tényező igazolódott, amelyek befolyásolhatják a spermiogenezis helyreállásának minőségét és időtartamát [45]. Az áttekintett 30 vizsgálatban a férfiak 94\%-át követték a 
6. táblázat | Férfi hormonális fogamzásgátlásra vizsgált hatóanyagok leggyakoribb mellékhatásai

\begin{tabular}{|c|c|c|c|c|}
\hline Hatóanyag & $\begin{array}{l}\text { Fizikális mellékhatások } \\
\text { (változások átlaga) }\end{array}$ & $\begin{array}{l}\text { Fizikális mellékhatások } \\
\text { (gyakoriság) }\end{array}$ & $\begin{array}{l}\text { Pszichés mellékhatások } \\
\text { (gyakoriság) }\end{array}$ & $\begin{array}{l}\text { Alkalmazási móddal összefügggó } \\
\text { mellékhatások (gyakoriság) }\end{array}$ \\
\hline Tesztoszteron-enantát & $\begin{array}{l}\text { Ts: }+3,7 \mathrm{~kg} ; \\
\text { Here tf: }-21,6 \% ; \\
\text { Hgb: }+6,2 \% ; \\
\text { Kol: }-6,5 \% \\
\text { HDL: }-12,6 \% \\
\text { LDL: }-5,6 \%\end{array}$ & Súlyos acne: $3,3 \%$ & $\begin{array}{l}\text { Agresszió: } 0,8-1,1 \% ; \\
\text { Hangulatváltozás: } 1,1 \%\end{array}$ & $\begin{array}{l}\text { Implantátumkilökődés: } 10 \% \\
\text { Implantátum-sebfertőzés: } \\
4,1 \%\end{array}$ \\
\hline Tesztoszteron-undekanoát & $\begin{array}{l}\text { Ts: }+0,4-4,8 \mathrm{~kg} ; \\
\text { Here tf: }-4-16 \% ; \\
\text { Hgb: }+7-9 \% ; \\
\text { Kol: }-21 \% ; \\
\text { HDL: }-23 \% ; \\
\text { LDL: }-29 \%\end{array}$ & $\begin{array}{l}\text { Acne: } 7,3 \% ; \\
\text { Köhögés: } 2,1 \%\end{array}$ & Nincs adat & $\begin{array}{l}\text { Injekció helyének fájdalma: } \\
3,9 \%\end{array}$ \\
\hline Tesztoszteron + levonorgestrel & $\begin{array}{l}\text { Ts: }+2,5-5,3 \mathrm{~kg} ; \\
\text { Here tf: }-15,3-32,1 \% \text {; } \\
\text { Htk: }+4,5-6,9 \% ; \\
\text { Kol: }-6,5-9,1 \% ; \\
\text { HDL: }-4,9-22,9 \% ; \\
\text { LDL: }-6,0-6,9 \%\end{array}$ & $\begin{array}{l}\text { Acne: } 15-83 \% \\
\text { Gynecomastia: } \\
4,7-35 \%\end{array}$ & Irritabilitás: 5-6,7\%; & $\begin{array}{l}\text { Tapasz helyén bőrirritáció: } \\
30 \%\end{array}$ \\
\hline $\begin{array}{l}\text { Tesztoszteron + etonogestrel } \\
\text { (desogestrel) }\end{array}$ & $\begin{array}{l}\text { Ts: }+1,5-6,5 \mathrm{~kg} ; \\
\text { Here tf: }-25-30 \% ; \\
\text { Hgb: }+2,0-5,7 \% ; \\
\text { Kol: }-4-10 \% ; \\
\text { HDL: }-4-22 \% ; \\
\text { SHBG: }-19-30 \%\end{array}$ & $\begin{array}{l}\text { Acne: } 12,5-29,1 \% ; \\
\text { Izzadás: } 27 \% \text {; } \\
\text { Arthralgia, laryngitis, } \\
\text { myocarditis, erectilis } \\
\text { diszfunkció eseten- } \\
\text { ként }\end{array}$ & $\begin{array}{l}\text { Hangulati eltérések: } \\
5,4-19 \% \text {; } \\
\text { Libidóváltozás: } 13 \%\end{array}$ & Nincs adat \\
\hline Tesztoszteron + nestoron & $\begin{array}{l}\text { Ts: }+2,5-5,2 \mathrm{~kg} \\
\text { HDL: }-1 \% \\
\text { Htk }+1 \%\end{array}$ & $\begin{array}{l}\text { Acne: } 17,9 \%, \\
\text { Fejfájás: } 17 \%\end{array}$ & $\begin{array}{l}\text { Depresszió és hangulat- } \\
\text { változás: } 8,9 \% \text {, } \\
\text { Álmatlanság: } 6 \%, \\
\text { Agresszió: } 2,9 \%, \\
\text { Libidócsökkenés: } 2,9 \%\end{array}$ & Nincs adat \\
\hline $\begin{array}{l}\text { Tesztoszteron + norethisteron- } \\
\text { enantát }\end{array}$ & Nincs adat & $\begin{array}{l}\text { Acne: } 45,9 \% ; \\
\text { Izomfájdalom: } 20,7 \% ; \\
\text { Gynecomastia: } 5,6 \% ; \\
\text { Fejfájás: } 5,3 \%\end{array}$ & $\begin{array}{l}\text { Libidónövekedés: } 38,1 \% ; \\
\text { Libidócsökkenés: } 4,1 \% \text {; } \\
\text { Hangulati eltérések: } 25,4 \% \text {; } \\
\text { Depresszió: } 2,8 \% ; \\
\text { Agresszió: } 1,9 \%\end{array}$ & $\begin{array}{l}\text { Injekció helyének fájdalma: } \\
23,1 \%\end{array}$ \\
\hline $\begin{array}{l}\text { Tesztoszteron }+ \text { depo } \\
\text { medroxiprogeszteron-acetát }\end{array}$ & Ts: $+2-2,9 \mathrm{~kg}$ & $\begin{array}{l}\text { Androgénhiányos } \\
\text { tünetek: } 3,6 \% \text {, acne: } \\
61,3 \%\end{array}$ & Hangulati zavarok: $1,8 \%$ & $\begin{array}{l}\text { Implantátummal kapcsolatos } \\
\text { panaszok: } 10,9 \% ; \\
\text { Bőrreakció a gélre: } 25 \%\end{array}$ \\
\hline $7 \alpha$-metil-19-nortesztoszteron & $\begin{array}{l}\text { Here tf: }-44 \% \\
\text { Hgb: }+6-8 \% \\
\text { Htk: }+6-10 \%\end{array}$ & Nincs adat & Nincs adat & Nincs adat \\
\hline
\end{tabular}

$\mathrm{HDL}=$ magas sûrűségű lipoprotein szérumszintje; Here tf = heretérfogat; Hgb = hemoglobi koncentráció; Htk = hematokrit; Kol = teljes szérumkoleszterin-szint; LDL = alacsony sűrűségű lipoprotein szérumszintje; SHBG = nemihormon-kötő fehérje szérumszintje; Ts = testsúly

20 millió/ml spermiumkoncentráció eléréséig és 60\%-át a teljes helyreállásig. Az adatok összesítése alapján a hormonális kezelés elhagyását követően hat hónappal a hím ivarsejtek termelődése 67\%, egy évvel később 90\%, két évvel később 100\% eséllyel éri el a 20 millió/ml koncentrációs értéket. Ugyanezek az eredmények 54\%, 83\%, $100 \%$, ha a férfiak tanulmány előtti, alap spermiumtermelődését vesszük figyelembe [45]. A helyreállás esélyét növeli az idősebb életkor, az ázsiai származás, a rövidebb fogamzásgátlási időtartam és rövidebb fél életidejű TEszármazék használata, az alacsonyabb kezdeti LH-szint, a gyorsabb szuppresszió és magasabb kezdeti spermiumkoncentráció [45].

\section{Egyéb, nem hormonális lehetőségek - kitekintés}

Az elmúlt időszakban a hormonális hatásmechanizmuson kívül más, a spermiogenezist, illetve a spermiumfunkciót befolyásoló módszerek is kutatási témává váltak. Ismertté vált, hogy a hím ivarsejtek mozgásához szükséges glikolízis folyamatában olyan izoenzimek vesznek részt (például az őssejtspecifikus glicerinaldehid-3-foszfát-dehidrogenáz), amelyek a szervezetben máshol nem fordulnak elő [46]. Szintén jellemző az a feszültségfüggô kalciumcsatorna (CatSper), amely a farokrész mozgásához elengedhetetlen. Ez a két támadáspont a jövőben 
a spermiumok mozgását gátolhatja, amely segítségével a hím ivarsejtek progresszív motilitása megszüntethető, így a fogamzásgátló hatás elérhető [47].

Alternatív lehetőség a Sertoli-sejtek és a korai fázisban lévő spermium-előalakok közötti sejt-sejt kapcsolat megszakítása, amely a spermiogenezis blokádját jelenti. $\mathrm{Az}$ erre alkalmas vegyületek (adjudin, gamendazol, CDB-4022) humán alkalmazása egyelőre vesekárosító hatásuk miatt nem kivitelezhető, de a jövőben a mellékhatásprofil optimalizálása mellett fogamzásgátlásra alkalmasak lehetnek [47].

Ismert, hogy a mellékhere szekrétumának proteázinhibitor-tartalma (epididymal protease inhibitor - EPPIN) a hím ivarsejtek motilitásához elengedhetetlen. Az EPPIN múködése immunológiai hatásmechanizmussal, lényegében egy anti-EPPIN-antitest-vakcinációval gátolható [48], így a hím ivarsejtek motilitása blokkolható.

Új megközelítést tett lehetővé az úgynevezett bromodomén fehérjerészletek szerepének felismerése a hím ivarsejtek kialakulásában. A spermatogonónium őssejtek intenzív proliferációja során szükséges a férfi genomjának megfelelő kondenzációja és a gyors változások folyamán az örökítőanyag integritásának maximális megőrzése. Az úgynevezett bromodomén szakaszokat tartalmazó fehérjék ennek a mechanizmusnak a szabályozásában vesznek részt. A bromodomént tartalmazó protein 4 (bromodomain-containing protein 4 - BRD4), illetve a bromodomén herespecifikus fehérje (bromodomain testis-specific protein - BRDT) eróteljesen gátolható triazolo-tieno-diazepinnel (JQ1), amely hatására a hímivarsejt-elöalakok sejtmagszerkezete károsodik, így a spermiumok érése egy köztes szakaszban leáll [49].

Szintén áttörést jelenthet az Izumol-Juno páros felfedezése. Az Izumol a spermium olyan felszíni fehérjéje, amely a petesejt Juno receptorához kötődve esszenciális a megtermékenyülés létrejöttében [50]. Ennek az interakciónak egy monoklonális antitesttel való gátlása szintén hatékony fogamzásgátlást jelenthet [47].

\section{Következtetés}

A férfi hormonális fogamzásgátlás a kutatások témája közel 50 éve, azonban továbbra sem sikerült olyan hatóanyag vagy hatóanyag-kombináció kifejlesztése, amely a széles körú használat kívánalmainak maradéktalanul megfelelne. A kellő fogamzásgátló hatás beálltának relatíve hosszú ideje, a kezelésre nem reagálók jelentős aránya, illetve a hatóanyag-beviteli módok kényelmetlen volta eddig megakadályozta a hatékony férfi hormonális fogamzásgátlás elérését. Az elmúlt időszakban a költségek és a nehézségek hatására a gyógyszeriparban, sajnos, az ilyen irányú fejlesztések valamelyest háttérbe szorultak. Ugyanakkor a növekvő igény arra, hogy a férfiak saját kontroll alatt tarthassák a fertilitásukat, remélhetően új lendületet ad majd a hasonló témájú gyógyszerfejlesztéseknek.
Anyagi támogatás: A közlemény megírása és az ahhoz kapcsolódó kutatómunka anyagi támogatásban nem részesült.

Szerzôi munkamegosztás: P. N.: Szakirodalmi kutatás, a szakirodalmi adatok elemzése, a kézirat szövegezése, a kézirat korrektúrázása. H. B. E., B. A.: Szakirodalmi kutatás, a szakirodalmi adatok elemzése, a kézirat szövegezése. N. G.: A kézirat szövegezése, a kézirat korrektúrázása. A cikk végleges változatát valamennyi szerző elolvasta és jóváhagyta.

Érdekeltségek: A szerzőknek nincsenek érdekeltségeik.

\section{Irodalom}

[1] Sedgh G, Singh S, Hussain R. Intended and unintended pregnancies worldwide in 2012 and recent trends. Stud Fam Plann. 2014; 45: 301-314.

[2] Tsui AO, McDonald-Mosley R, Burke AE. Family planning and the burden of unintended pregnancies. Epidemiol Rev. 2010; 32: 152-174.

[3] Johnson S, Pion C, Jennings V. Current methods and attitudes of women towards contraception in Europe and America. Reprod Health 2013; 10: 7.

[4] Kozinszky Z, Bártfai G. Contraceptive behaviour of teenagers requesting abortion. Eur J Obstet Gynecol Reprod Biol. 2004; 112: 80-83.

[5] Ross J, Hardee K. Use of male methods of contraception worldwide. J Biosoc Sci. 2017; 49: 648-663

[6] Kopa Zs. Male contraception. In: Papp Z. (ed.) Handbook of gynecology. [A férfi fogamzásgátlás. In: Papp Z. (szerk.) A nőgyógyászat kézikönyve.] Medicina Könyvkiadó, Budapest, 2017; pp. 271-276. [Hungarian]

[7] Dohle GR, Diemer T, Kopa Z, et al. European Association of Urology guidelines on vasectomy. Eur Urol. 2012; 61: 159-163.

[8] Elek C, Dudás I, Czeizel E. Surgical sterilization and health practices in birth control policy. [A múvi meddôvététel és az egészségkultúra a születéskorlátozásban.] Orv Hetil. 1990; 131: 887. [Hungarian]

[9] Herrel LA, Goodman M, Goldstein M, et al. Outcomes of microsurgical vasovasostomy for vasectomy reversal: a meta-analysis and systematic review. Urology 2015; 85: 819-825.

[10] Martin CW, Anderson RA, Cheng L, et al. Potential impact of hormonal male contraception: cross-cultural implications for development of novel preparations. Hum Reprod. 2000; 15: 637645.

[11] Chao JH, Page ST. The current state of male hormonal contraception. Pharmacol Ther. 2016; 163: 109-117.

[12] World Health Organization Task Force on Methods for the Regulation of Male Fertility. Contraceptive efficacy of testosteroneinduced azoospermia in normal men. Lancet 1990; 336: 955959.

[13] World Health Organization Task Force on Methods for the Regulation of Male Fertility. Contraceptive efficacy of testosteroneinduced azoospermia and oligozoospermia in normal men. Fertil Steril. 1996; 65: 821-829.

[14] McLachlan RI, McDonald J, Rushford D. Efficacy and acceptability of testosterone implants, alone or in combination with a 5alpha-reductase inhibitor, for male hormonal contraception. Contraception 2000; 62: 73-78.

[15] Wang C, Wang XH, Nelson AL, et al. Levonorgestrel implants enhanced the suppression of spermatogenesis by testosterone implants: comparison between Chinese and non-Chinese men. J Clin Endocrinol Metab. 2006; 91: 460-470. 
[16] Glasier A. Acceptability of contraception for men: a review. Contraception 2010; 82: 453-456.

[17] Yin AY, Htun M, Swerdloff RS, et al. Reexamination of pharmacokinetics of oral testosterone undecanoate in hypogonadal men with a new self-emulsifying formulation. J Androl. 2012; 33: 190-201.

[18] Gonzalo IT, Swerdloff RS, Nelson AL, et al. Levonorgestrel implants (Norplant II) for male contraception clinical trials: combination with transdermal and injectable testosterone. J Clin Endocrinol Metab. 2002; 87: 3562-3572.

[19] Zhang GY, Gu YQ, Wang XH, et al. A pharmacokinetic study of injectable testosterone undecanoate in hypogonadal men. J Androl. 1998; 19: 761-768.

[20] Gu YQ, Wang XH, Xu D, et al. A multicenter contraceptive efficacy study of injectable testosterone undecanoate in healthy Chinese men. J Clin Endocrinol Metab. 2003; 88: 562-568.

[21] Gu Y, Liang X, Wu W, et al. Multicenter contraceptive efficacy trial of injectable testosterone undecanoate in Chinese men. J Clin Endocrinol Metab. 2009; 94: 1910-1915.

[22] Handelsman DJ, Mackey MA, Howe C. An analysis of testosterone implants for androgen replacement therapy. Clin Endocrinol (Oxf). 1997; 47: 311-316.

[23] Attardi BJ, Koduri S, Hild SA. Relative progestational and an drogenic activity of four progestins used for male hormonal contraception assessed in vitro in relation to their ability to suppress LH secretion in the castrate male rat. Mol Cell Endocrinol. 2010; 328: 16-21.

[24] Zitzmann M, Rohayem J, Raidt J, et al. Impact of various progestins with or without transdermal testosterone on gonadotropin levels for non-invasive hormonal male contraception: a randomized clinical trial. Andrology 2017; 5: 516-526.

[25] Bebb RA, Anawalt BD, Christensen RB, et al. Combined administration of levonorgestrel and testosterone induces more rapid and effective suppression of spermatogenesis than testosterone alone: a promising male contraceptive approach. J Clin Endocrinol Metab. 1996; 81: 757-762.

[26] Anawalt BD, Amory JK, Herbst KL, et al. Intramuscular testosterone enanthate plus very low dosage oral levonorgestrel suppresses spermatogenesis without causing weight gain in normal young men: a randomized clinical trial. J Androl. 2005; 26 405-413.

[27] Hay CJ, Brady BM, Zitzmann M, et al. A multicenter phase IIb study of a novel combination of intramuscular androgen (testosterone decanoate) and oral progestogen (etonogestrel) for male hormonal contraception. J Clin Endocrinol Metab. 2005; 90 2042-2049.

[28] Anawalt BD, Herbst KL, Matsumoto AM, et al. Desogestrel plus testosterone effectively suppresses spermatogenesis but also causes modest weight gain and high-density lipoprotein suppression. Fertil Steril. 2000; 74: 707-714.

[29] Brady BM, Amory JK, Perheentupa A, et al. A multicentre study investigating subcutaneous etonogestrel implants with injectable testosterone decanoate as a potential long-acting male contraceptive. Hum Reprod. 2006; 21 : 285-294.

[30] Mommers E, Kersemaekers WM, Elliesen J, et al. Male hormonal contraception: a double-blind, placebo-controlled study. J Clin Endocrinol Metab. 2008; 93: 2572-2580.

[31] Ilani N, Roth MY, Amory JK, et al. A new combination of testosterone and nestorone transdermal gels for male hormonal contraception. J Clin Endocrinol Metab. 2012; 97: 3476-3486.

[32] Roth MY, Shih G, Ilani N, et al. Acceptability of a transdermal gel-based male hormonal contraceptive in a randomized controlled trial. Contraception 2014; 90: 407-412.

[33] Roth MY, Ilani N, Wang C, et al. Characteristics associated with suppression of spermatogenesis in a male hormonal contraceptive trial using testosterone and Nestorone ${ }^{\circledast}$ gels. Andrology 2013; 1: 899-905.
[34] Behre HM, Zitzmann M, Anderson RA, et al. Efficacy and safety of an injectable combination hormonal contraceptive for men. J Clin Endocrinol Metab. 2016; 101: 4779-4788.

[35] Qoubaitary A, Meriggiola C, Ng CM, et al. Pharmacokinetics of testosterone undecanoate injected alone or in combination with norethisterone enanthate in healthy men. J Androl. 2006; 27 : 853-867.

[36] Page ST, Amory JK, Anawalt BD, et al. Testosterone gel combined with depomedroxyprogesterone acetate is an effective male hormonal contraceptive regimen and is not enhanced by the addition of a GnRH antagonist. J Clin Endocrinol Metab. 2006; 91: 4374-4380.

[37] Turner L, Conway AJ, Jimenez M, et al. Contraceptive efficacy of a depot progestin and androgen combination in men. J Clin Endocrinol Metab. 2003; 88: 4659-4667.

[38] Roth MY, Nya-Ngatchou JJ, Lin K, et al. Androgen synthesis in the gonadotropin-suppressed human testes can be markedly suppressed by ketoconazole. J Clin Endocrinol Metab. 2013; 98: 1198-1206

[39] Surampudi P, Page ST, Swerdloff RS, et al. Single, escalating dose pharmacokinetics, safety and food effects of a new oral androgen dimethandrolone undecanoate in man: a prototype oral male hormonal contraceptive. Andrology 2014; 2: 579-587.

[40] Von Eckardstein S, Noe G, Brache V, et al. A clinical trial of 7 alpha-methyl-19-nortestosterone implants for possible use as a long-acting contraceptive for men. J Clin Endocrinol Metab. 2003; 88: 5232-5239.

[41] Walton MJ, Kumar N, Baird DT, et al. 7alpha-methyl-19-nortestosterone (MENT) vs testosterone in combination with etonogestrel implants for spermatogenic suppression in healthy men. J Androl. 2007; 28: 679-688.

[42] McLachlan RI, Robertson DM, Pruysers E, et al. Relationship between serum gonadotropins and spermatogenic suppression in men undergoing steroidal contraceptive treatment. J Clin Endocrinol Metab. 2004; 89: 142-149.

[43] Page ST, Kalhorn TF, Bremner WJ, et al. Intratesticular androgens and spermatogenesis during severe gonadotropin suppression induced by male hormonal contraceptive treatment. J Androl. 2007; 28: 734-741.

[44] Fernández-Balsells MM, Murad MH, Lane M, et al. Clinical review 1: Adverse effects of testosterone therapy in adult men: a systematic review and meta-analysis. J Clin Endocrinol Metab. 2010; 95: 2560-2575.

[45] Liu PY, Swerdloff RS, Christenson PD, et al. Rate, extent, and modifiers of spermatogenic recovery after hormonal male contraception: an integrated analysis. Lancet 2006; 367: 1412-1420.

[46] Krisfalusi M, Miki K, Magyar PL. Multiple glycolytic enzymes are tightly bound to the fibrous sheath of mouse spermatozoa. Biol Reprod. 2006; 75: 270-278.

[47] Zdrojewicz Z, Konieczny R, Papier P, et al. Brdt bromodomains inhibitors and other modern means of male contraception. Adv Clin Exp Med. 2015; 24: 705-714.

[48] O'Rand MG, Silva EJ, Hamil KG. Non-hormonal male contraception: A review and development of an Eppin based contraceptive. Pharmacol Ther. 2016; 157: 105-111.

[49] Barda S, Paz G, Yogev L. Expression of BET genes in testis of men with different spermatogenic impairments. Fertil Steril. 2012; 97: 46-52.e5

[50] Bianchi E, Doe B, Goulding D, et al. Juno is the egg Izumo receptor and is essential for mammalian fertilization. Nature 2014; 508: 483-487.

(Pásztor Norbert dr., Szeged, Semmelweis u. 1., 6725 e-mail: hirt78@gmail.com) 